\title{
Restorative Prospective of Powdered Seeds Extract of Garcinia kola in Chrysichthys furcatus Induced with Glyphosate Formulation
}

\author{
T. O. Ikpesu, ${ }^{1}$ I. Tongo, ${ }^{2}$ and A. Ariyo ${ }^{1}$ \\ ${ }^{1}$ Department of Biological Sciences, Federal University Otuoke, Nigeria \\ ${ }^{2}$ Department of Animal and Environmental Biology (AEB), University of Benin, Benin City, Nigeria \\ Correspondence should be addressed to T. O. Ikpesu; tomohwofasa@yahoo.com
}

Received 23 September 2013; Accepted 20 October 2013; Published 21 January 2014

Academic Editors: Y. Chen and Z. Qiusheng

Copyright ( $\odot 2014$ T. O. Ikpesu et al. This is an open access article distributed under the Creative Commons Attribution License, which permits unrestricted use, distribution, and reproduction in any medium, provided the original work is properly cited.

Responses of Chrysichthys furcatus to glyphosate formulation and Garcinia kola seed extracts were investigated using the organization for Economic Cooperation and Development numbers 203 and 407 recommended toxicity bioassay. The fish were divided into five groups and exposed to different treatments of glyphosate formulation and Garcinia kola seed extract, with the control serving as a reference. Water quality parameters and blood chemistry were estimated in the experimental and control fish at the end of 28 days. There was no significant difference $(P>0.05)$ between fish treated with glyphosate formulation alone and other treatments except for dissolved oxygen which was highly significant $(P<0.01)$ between fish treated with glyphosate formulation alone and other treatments and the control. All the blood parameters were significantly $(P<0.05)$ affected by glyphosate formulation when compared with the control. The changes observed in glyphosate formulation alone were reversible when G. kola seeds extract was added and was dose dependent. The plant's extract has shown to be a good remedy to pollutants, and formulations of the seed extract into tablets or capsules could serve as antidote to ameliorate the effects of pollutants. This finding can reduce the risk of biomagnifications of poisons along the food chain.

\section{Introduction}

In the last few years there has been an exponential growth in the field of herbal medicine and these drugs are gaining popularity both in developing and developed countries because of their natural origin and less side effects [1]. Herbal products cause few adverse effects but have beneficial pharmacological and therapeutic uses in a number of illnesses, including HIV where they have been examined for their capacity to reduce symptoms and improve quality of life [2]. The literature review had shown that oral administration of an aqueous $T$. cordifolia root extract to alloxan diabetic rats caused a significant reduction in blood glucose and brain lipids. Though the aqueous extract at a dose of $400 \mathrm{mg} / \mathrm{kg}$ could elicit significant antihyperglycemic effect in different animal models, its effect was equivalent to only one unit $/ \mathrm{kg}$ of insulin [3]. It is reported that the daily administration of either alcoholic or aqueous extract of T. cordifolia decreases the blood glucose level and increases glucose tolerance in rodents [4]. Also, oral administration of 2 and $8 \mathrm{~g} / \mathrm{kg}$ of plant extract of fenugreek seeds produced dose dependent decrease in the blood glucose levels in both normal diabetic rats [5]. The plant's seed extract also improved glucose metabolism and normalized creatinine kinase activity in heart, skeletal muscle, and liver of diabetic rat [6]. Similarly, methanolic extract of Phyllanthus amarus was found to have potent antioxidant activity and reduced the blood sugar in alloxanized diabetic rats [7].

Garcinia kola (commonly called bitter kola) is an economic and highly valued tree available in large quantity in West Africa. The fruit, seeds, nuts, and bark of the plant have been used extensively in African traditional medicine for the treatment of various diseases [8]. The active constituent of the plant is dimeric flavonoid molecules fused together by biflavonoid. Other constituents include xanthones and benzophenones [9]. The dry powdered seeds contain $0.003 \%$ of flavonoids while the crude extract contained $0.007 \%$ of 
flavonoids based on rutin used as the standard [10]. The seeds when chewed have a bitter astringent taste. Garcinia species are known to elaborate a complex mixture of phenolic compounds including biflavonoids, xanthones, and benzophenones.

Bitter kola has been used as an antidote for cases of poisons or suspected poisons. When food is suspected to be contaminated by bacteria, bitter kola is chewed to prevent the development of any infection or poisoning. The plant products also contain chemical compounds that help in the breakdown of glycogen in the liver. This is because the phenolic compounds present in bitter kola possess antiinflammatory, antimicrobial, antidiabetic, and antiviral properties [11].

Several studies on G. kola have confirmed its hypolipidemic [11], antihistanic [12], and antimicrobial effects [13]. The presence of biflavonoids and xanthone in G. kola seeds has been confirmed [14]. Administration of G. kola seed extracts caused an increase in testosterone production in Sprague-Dawley rats $[15,16]$. The seed extract and dry powdered seed of $G$. kola plants have been made into various forms including tablets, cream, and toothpaste [13]. These ensure dosage precision, since herbal medicines have been widely criticized due to lack of standardization. Also formulation of $G$. kola into a modern pharmaceutical conventional tablet dosage form would confer on it many of the good properties of tablets. Some examples include ease of administration, greater acceptance due to presentation, prolonged shelf life, quality assurance, greater accuracy in dispensing, and reduction in transportation cost arising perhaps from formulation into less bulky dosage form [17].

When the pesticide enters aquatic systems either through accidental spraying, spray drift, or surface runoff, it dissipates rapidly from the water column as a result of adsorption and possibly biodegradation. Glyphosate is a broad-spectrum nonselective systemic herbicide, registered for use on many food and nonfood crops as well as noncrop areas where total vegetation control is desired. When applied at lower rates, it serves as a plant growth regulator [18]. The herbicide has been approved by regulatory bodies worldwide and is effective in killing a wide variety of plants, including grasses, broadleaf, and woody plants. It is marketed with the following trade names: Roundup, Rondo, Sting, Rodeo, Spasor, Muster, Tumbleweed, Sonic, Glifonox, and Glycel. Sediment is the primary sink for glyphosate and after spraying its levels in sediment rise and then decline to low levels in a few months [19]. It is very toxic to earthworms and beneficial insects $[20,21]$. Frog embryos treated with glyphosate formulation and pure glyphosate alone suffered diminution of body size, alterations of brain morphology, reduction of the eyes, alterations of the branchial arches and optic placodes, alterations of the neural plate, and other abnormalities of the nervous system [22]. When absorbed into plants, it delays soil degradation and can increase glyphosate persistence in soil from two to six times [23]. Because of this known toxicity, only some formulations of glyphosate are registered for use in aquatic applications [24].
By volume, the herbicide is one of the most widely used herbicides [18]. The pesticide formulations do contain surfactants (detergents) to help the active ingredient penetrate the waxy cuticle of the plant and are more toxic to aquatic organisms than glyphosate alone $[25,26]$. The pesticide is readily available as formulated compound. This research, therefore, is to examine the prospect of using G. kola seed extracts to ameliorate the water quality and to restore the blood chemistry of fish induced with glyphosate formulation.

\section{Materials and Methods}

2.1. Chemical Analysis. Glyphosate (99.5\% purity) and methanol (analytical grade) for high performance liquid chromatography (HPLC) were obtained from Chemical Service (West Chester, PA, USA). $\mathrm{Na}_{2} \mathrm{SO}_{4}$ (99\% purity), petroleum ether (analytical grade), acetonitrile (analytical grade), ethyl 3-aminobenzoate methanesulfonate salt (Sigma-Aldrich, USA), and bovine serum albumin (BSA) used for the determination of protein quantity were supplied by Sigma Chemical Company St Louis, MO, USA. High purity pesticide grade solvents (hexane, dichloromethane, and the surrogate standard solution) were obtained from Merck (Darmstadt, Germany) and helium (purity 99.999\%) from Messer Technogas (Czech Republic).

2.2. Equipment. Equipment included heparinized syringe, glassware, Cecil HPLC system comprised of CE 1200 high performance variable wavelength monitor and CEII00 liquid chromatography pump, high-resolution gas chromatography (HRGC), and UV detector with variable wavelength and stainless steel column (C18 Reverse phase) packed with Octasilica, vacuum pump, and ultrasonic check.

2.3. Collection and Acclimatization of Test Organisms. One hundred and fifty postjuveniles stage of $C$. furcatus of mean weight $(30.00+0.13 \mathrm{~g})$ and length $(13.09+0.2 \mathrm{~cm})$ from fresh water environment were collected from a private farm (Patiby Agro Industrial Enterprise) from Erawa Owhe, Delta State, Nigeria. They were acclimatized to laboratory conditions in holding glass tanks containing deionized water for two weeks before they were used for the experiments. The holding tanks were aerated with the help of air pump, cleaned, and water renewed daily. Fish were fed on 30\% protein pellets, unconsumed feed and faecal wastes were removed, and water was replenished regularly as recommended in [27].

2.3.1. Collection and Processing of Seeds. Matured G. kola seeds were obtained from a private farm at Walode, Osun State, Nigeria. Brown coated seeds were manually removed from the pod and air dried for five days. The dried brown coat was hand peeled, and the seeds were cut into pieces and redried at room temperature $(22+0.15)^{\circ} \mathrm{C}$ for three months. The seeds sample was grounded using Nakai blender (dry mill), filtered through a 40-mesh screen, and extracted for 7 hours using the Soxhlet apparatus as described in [10] with slight modification. 
2.3.2. Extraction of the Powdered Seeds. One hundred gram $(100 \mathrm{~g})$ of the powder of $\mathrm{G}$. kola was spiked with a solution of surrogate standard (d8-naphthalene, d10-acenaphthene, d12chrysene, and d12-perylene) and extracted with a mixture of dichloromethane and $\mathrm{n}$-hexane in a ratio $2: 3$, having been subjected to a vigorous shaking in a sonication bath for 5 hours. The solvent was separated, concentrated using a rotatory evaporator, and eluted with methanol. The eluted solvent was transferred into an open $250 \mathrm{~mL}$ conical flask in a placid environment for 48 hours to evaporate the methanol.

2.4. Experimental Design. The concentrations of glyphosate formulation for the test were prepared from the stock solution via serial dilution. Stock solution, test water concentrations, and G. kola seed extract concentration were verified by Cecil HPLC system comprised of CE 1200 high performance variable wavelength monitor, and CEII00 liquid chromatography pump, and high-resolution gas chromatography (HRGC), using a Hewlett-Packard 5890 capillary gas chromatograph (Hewlett-Packard, Avondale, PA, USA) equipped with an electron capture detector (Hewlett-Packard).

2.5. Acute Test. The fish were determined to be free of external parasites prior to the exposure. The test was conducted under OECD Guideline number 203 for static-renewal test conditions $[28,29]$ with some modification. Fifteen glass aquaria were used for this study, with three replicates per treatment. Each aquarium contains different concentrations of the toxicant. All experiments were conducted at room temperature and the tanks were properly aerated. Fish were not fed during the experiment [30]. Thirty minutes after the preparation of test solution, 5 postjuveniles were carefully placed into each tank with their replicate tanks of five different concentrations including the control $(0.00,1.50$, $3.00,4.50$ and $6.0 \mathrm{mg} / \mathrm{L}$ ). Seventy-five percent of the test solution was renewed each day and aerated with the aid of air pump. Fish and water quality parameters $(\mathrm{pH}$, temperature, dissolved oxygen, turbidity, alkalinity, and total hardness) of the test solution were determined at $24 \mathrm{hr}$ interval, using standard methods. Cumulative fish mortality was recorded at $24,48,72$, and $96 \mathrm{~h}$ time intervals and the $\mathrm{LC}_{50} \mathrm{~s}$ of each period calculated using the lethal computer program developed by Finney [31]. Experiment lasted for 96 hrs for the different concentrations of the pesticide.

2.6. Chronic Test. The chronic test was conducted under OECD test guideline 407 [32]. From the result of acute toxicity, sublethal concentrations $(0.00,0.08,0.12,0.16$ and $0.32 \mathrm{mg} / \mathrm{L}$ ) were prepared. Fifteen glass aquaria were also used with 3 replicates per treatment and with the same conditions as in acute toxicity. The fish were divided into five groups of ten postjuveniles per test concentration in three replicates. Group A was given distilled water as contained in the experimental doses, and group B was treated with $0.16 \mathrm{mg} / \mathrm{L}$ glyphosate formulation only, while other groups were exposed to the same concentration as in group A but with different concentrations of $G$. kola seed extract. Groups C, D, and E received 150, 250, and $350 \mathrm{mg} / \mathrm{L}$ of $\mathrm{G}$. kola seeds extract, respectively.
Fish and water quality parameters $(\mathrm{pH}$, temperature, dissolved oxygen, turbidity, alkalinity, and hardness) of the test solution were monitored throughout the duration of the experiment. Signs of stress such as loss of coordination, unusual lethargy, erratic behaviour, and gasping of air were monitored throughout the period of experiment.

Blood indices (erythrocytes, leucothytes, haemoglobin, haematocrit, and the metabolites) carbohydrates, protein and hydrocortisone, a steroid hormone were estimated in the experimental and control fish at the end of 28 days of exposure.

2.7. Water Quality. Total hardness and total alkalinity were measured by the titration method [33]. Dissolved oxygen concentration was measured by the Winkler method [33]. Water temperature and $\mathrm{pH}$ were determined with a glass electrode (Thermo Orion, Beverly, MA, USA).

2.8. Blood Collection. At the end of the 28 days, the fish were removed from aquaria and immediately anesthetized with MS222 (ethyl 3-aminobenzoate methanesulfonate salt, Sigma). Blood samples were taken by puncturing the caudal vessels with a 20-gauge needle and aspirating $0.2-0.4 \mathrm{~mL}$ sample of mixed arterial and venous blood into a heparinized syringe, a technique shown to minimize dilution by tissue fluids [34]. The blood samples were stored in heparinized blood collecting duct for the estimation of total erythrocyte count (TEC), total leucocyte count (TLC), haemoglobin and carbohydrates level. Similarly, blood was collected in plane bottles (without anticoagulants) and stored at $-20^{\circ} \mathrm{C}$ for protein and hydrocortisone analysis. The blood was allowed to clot for $30 \mathrm{~min}$, centrifuged at $2000 \mathrm{~g}$ for $15 \mathrm{~min}$ for clear separation of the serum, and stored at $-80^{\circ} \mathrm{C}$ until the analysis.

2.9. Blood Cells Determination. The whole blood was used for the estimation of the blood count. Erythrocytes and leucocytes were counted by method of [35] as modified by [36] using haemocytometer. Haemoglobin content was estimated by Cyanmethaemoglobin method [37] as modified by [35] while haematocrit was estimated using microhematocrit method [38].

2.10. Biochemical Parameters. Changes in carbohydrates metabolism were determined by the method of Folin and Malmros microprocedure as modified by [39] and verified by using the enzymatic-calorimetric method [40]. Bovine serum albumin (BSA) used for the determination of protein quantity was purchased from Sigma Chemical Company St Louis, MO, USA. Protein determination was performed using the original Lowry method [41]. Electrochemiluminometric assay was used in the determination of the hydrocortisone levels. The test kit was prepared in accordance with the method described in [42] as modified in [43].

2.11. Statistical Analysis. The susceptibility of juveniles of $C$. furcatus to glyphosate formulation and responses to various treatments of G. kola seed extract were determined using the probit (Probit software) method for analysis [31] for $\mathrm{LC}_{50}$ at 


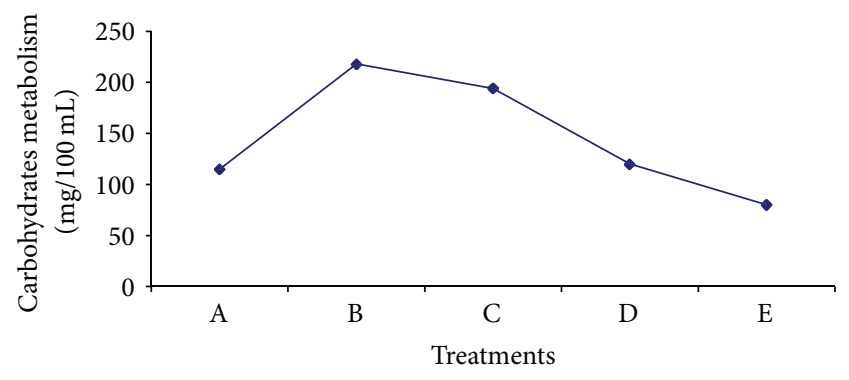

FIGURE 1: Changes in carbohydrates metabolism $(\mathrm{mg} / 100 \mathrm{~mL})$ in Chrysichthys furcatus exposed to different treatments of glyphosate formulation and Garcinia kola seed extracts after 28 days.

96 hrs. Student's $t$-test and one-way analysis of variance [44, 45 ] were used to test for significant differences in the values of the parameters in control fish and various treatments; $P$ values of 0.05 or less were considered statistically significant [46].

\section{Results}

3.1. Physicochemical Properties of the Test Media. The water quality parameters ( $\mathrm{pH}$, temperature, dissolved oxygen, turbidity, alkalinity, and total hardness) monitored during the exposure periods were not significantly different between fish treated with glyphosate formulation alone and other treatments $(P>0.05, F=5.6)$ except for dissolved oxygen which was highly significant $(P<0.01)$ between fish treated with glyphosate formulation alone and other treatments and the control (Table 1).

3.2. Haematological Indices. The responses of various haemathological indices in C. furcatus exposed to glyphosate formulation alone and other treatments are shown in Table 2. All the treatments vary significantly $(P<0.05)$ between the control and various treatments except the glyphosate formulation treated with $250 \mathrm{mg} / \mathrm{L} \mathrm{G}$. kola seeds extract. However, erythrocyte sedimentation rate (ESR) showed no significant difference between the control and glyphosate formulation treated with $250 \mathrm{mg} / \mathrm{L} \mathrm{G}$. kola seeds extract $(P>$ $0.05, F=7.6)$.

\subsection{Metabolites}

3.3.1. Carbohydrates. Changes in carbohydrates metabolism in $C$. furcatus exposed to various treatments of glyphosate formulation alone and treatments with $G$. kola seeds extract are shown in Figure 1. Carbohydrates metabolism between the control and glyphosate formulation treated with various concentrations of $G$. kola seeds extract varies significantly $(P<0.05)$. However, carbohydrates metabolism in treatments D and E (250 mg/L and $350 \mathrm{mg} / \mathrm{L}$ G. kola seeds extract) is comparable with the control.

3.3.2. Protein. Protein metabolism in fish exposed to various treatments of glyphosate and $G$. kola seeds extract is shown in Figure 2. Protein metabolism in glyphosate formulation treated fish and the control fish and treatments D and E was

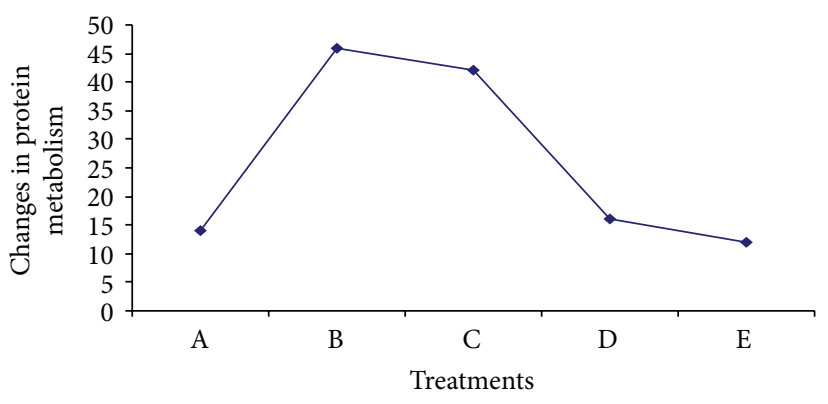

FIGURE 2: Variation in the serum protein $(\mathrm{mg} / 100 \mathrm{~mL})$ in Chrysichthys furcatus exposed to different treatments of glyphosate formulation and Garcinia kola seed extracts after 28 days.

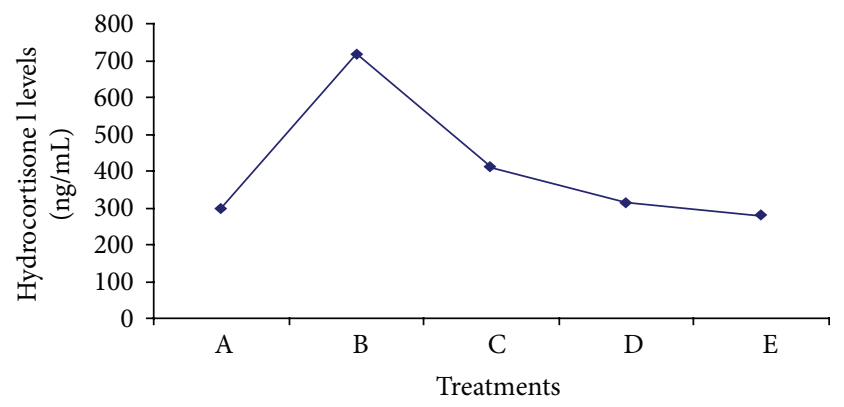

FIGURE 3: Hydrocortisone 1 levels $(\mathrm{ng} / \mathrm{mL})$ in the serum of Chrysichthys furcatus exposed to different treatments of glyphosate formulation and Garcinia kola seed extracts after 28 days.

highly significant $(P<0.01, F=4.7)$ and between glyphosate formulation and treatment $\mathrm{C}$ was significant $(P<0.05, F=$ 6.0). There was no significant difference $(P>0.05)$ between the control and treatments C, D and E.

\subsection{Steroid Hormone}

3.4.1. Hydrocortisone. Hydrocortisone secretion in this investigation is shown in Figure 3. Comparing the control and various treatments, the hormone secretion was significantly affected $(P<0.05)$ between the control and glyphosate formulation treatment alone and $\mathrm{C}$ (glyphosate formulation and $150 \mathrm{mg} / \mathrm{L}$ G. kola seeds extract). Treatments D and E were comparable with the control.

\section{Discussion}

4.1. Physicochemical Parameters. The changes in water parameters and the responses of $C$. furcatus to the treatment of glyphosate formulation and various concentrations of the seed extract of $G$. kola showed no significant change when comparing the control group with the treated groups, except for the dissolved oxygen which was significantly $(P<0.05)$ affected in glyphosate formulation treated alone. Also, only in treatment D (G. kola seed extract treated with $250 \mathrm{mg} / \mathrm{L}$ extract) the dissolved oxygen is comparable to the control. An observation showed that the plant extracts cleansing property is dose dependent. Dissolve oxygen is 
TABLE 1: Concentrations of physiochemical parameters of the test media.

\begin{tabular}{lcccccc}
\hline Treatments & pH & Temp. $\left({ }^{\circ} \mathrm{C}\right)$ & DO $(\mathrm{mg} / \mathrm{L})$ & $\begin{array}{c}\text { Parameters } \\
\text { Turbidity }(\mathrm{mg} / \mathrm{L})\end{array}$ & $\begin{array}{c}\text { Alkalinity }(\mathrm{mg} / \mathrm{L}) \\
\text { Mean } \pm \text { SD }\end{array}$ & $\begin{array}{c}\text { Hardness }(\mathrm{mg} / \mathrm{L}) \\
\text { Mean } \pm \text { SD }\end{array}$ \\
\hline A & $7.32 \pm 0.02^{\mathrm{a}}$ & $25.67 \pm 0.16^{\mathrm{a}}$ & $7.10 \pm 0.22^{\mathrm{a}}$ & $0.23 \pm 0.04^{\mathrm{a}}$ & $17.40 \pm 0.72^{\mathrm{a}}$ & $31.23 \pm 1.15^{\mathrm{a}}$ \\
B & $7.36 \pm 0.16^{\mathrm{a}}$ & $25.00 \pm 0.30^{\mathrm{a}}$ & $5.12 \pm 0.19^{\mathrm{b}}$ & $0.23 \pm 0.06^{\mathrm{a}}$ & $17.63 \pm 0.42^{\mathrm{a}}$ & $31.33 \pm 1.15^{\mathrm{a}}$ \\
C & $7.25 \pm 0.10^{\mathrm{a}}$ & $27.33 \pm 0.68^{\mathrm{a}}$ & $7.30 \pm 0.31^{\mathrm{a}}$ & $0.24 \pm 0.02^{\mathrm{a}}$ & $17.40 \pm 0.36^{\mathrm{a}}$ & $31.20 \pm 1.02^{\mathrm{a}}$ \\
D & $7.52 \pm 0.25^{\mathrm{a}}$ & $27.00 \pm 1.20^{\mathrm{a}}$ & $7.03 \pm 0.22^{\mathrm{a}}$ & $0.25 \pm 0.04^{\mathrm{a}}$ & $17.13 \pm 1.20^{\mathrm{a}}$ & $30.60 \pm 0.50^{\mathrm{a}}$ \\
E & $7.32 \pm 0.20^{\mathrm{a}}$ & $26.33 \pm 0.48^{\mathrm{a}}$ & $7.16 \pm 0.02^{\mathrm{a}}$ & $0.26 \pm 0.03^{\mathrm{a}}$ & $17.23 \pm 0.12^{\mathrm{a}}$ & $30.60 \pm 0.16^{\mathrm{a}}$ \\
\hline
\end{tabular}

Means with different superscripts in the column are significantly different ${ }^{*}(P<0.05)$.

TABLE 2: Blood indices in Chrysichthys furcatus treated with glyphosate formulation and different concentrations of Garcinia kola seed extract.

\begin{tabular}{|c|c|c|c|c|c|}
\hline \multirow{3}{*}{ Treatments } & \multicolumn{5}{|c|}{ Blood indices } \\
\hline & $\mathrm{RBC}(\mathrm{mill} / \mathrm{cmm})$ & $\operatorname{WBC}\left(\mathrm{G} \cdot 1^{-1}\right)$ & Haemoglobin $(\mathrm{g} / \mathrm{L})$ & PCV (\%) & $\operatorname{ESR}(\mathrm{mm} / \mathrm{hr})$ \\
\hline & Mean \pm SD & Mean \pm SD & Mean \pm SD & Mean \pm SD & Mean \pm SD \\
\hline A & $11.02 \pm 0.06^{\mathrm{a}}$ & $25.00 \pm 0.16^{\mathrm{a}}$ & $9.20 \pm 0.16^{\mathrm{a}}$ & $0.58 \pm 0.10^{\mathrm{a}}$ & $27.00 \pm 1.10^{\mathrm{a}}$ \\
\hline B & $4.13 \pm 0.11^{\mathrm{b}}$ & $83.80 \pm 0.30^{\mathrm{b}}$ & $3.10 \pm 1.10^{\mathrm{b}}$ & $0.16 \pm 0.10^{\mathrm{b}}$ & $8.70 \pm 1.13^{\mathrm{b}}$ \\
\hline $\mathrm{C}$ & $7.11 \pm 0.13^{\mathrm{c}}$ & $42.00 \pm 0.68^{c}$ & $5.16 \pm 0.11^{\mathrm{c}}$ & $0.29 \pm 0.05^{\mathrm{c}}$ & $21.50 \pm 0.16^{\mathrm{c}}$ \\
\hline $\mathrm{D}$ & $11.17 \pm 0.20^{\mathrm{a}}$ & $26.00 \pm 1.20^{\mathrm{a}}$ & $9.00 \pm 1.10^{\mathrm{a}}$ & $0.62 \pm 0.09^{\mathrm{a}}$ & $27.30 \pm 0.11^{\mathrm{a}}$ \\
\hline $\mathrm{E}$ & $9.16 \pm 0.13^{\mathrm{d}}$ & $35.00 \pm 0.48^{\mathrm{d}}$ & $6.10 \pm 0.05^{\mathfrak{c}}$ & $0.49 \pm 1.02^{\mathrm{d}}$ & $25.50 \pm 0.13^{\mathrm{a}}$ \\
\hline
\end{tabular}

Means with different superscripts in the column are significantly different ${ }^{*}(P<0.05)$.

very important in aquatic ecosystem; it brings out various biochemical changes and it influences metabolic activities in organisms; a good quality water should have the solubility of oxygen $7.0 \mathrm{mg} / \mathrm{L}$ at $30^{\circ} \mathrm{C}[47,48]$, which is within the range observed in the control and G. kola seed extract treated with $250 \mathrm{mg} / \mathrm{L}$ seeds extract.

4.2. Haemathological Indices. Haematological indices are usually altered during diseases or malnutrition conditions, are very sensitive to various environmental factors and chemicals, and can provide substantial diagnostic information [49]. On the basis of haematological studies, it would be possible to predict the physiological state of fish in natural water bodies [50]. Differences in blood parameters of fish in this investigation could therefore be attributed to glyphosate formulation which were significantly high $(P<0.05)$ when compared with the control and other treatments. All the measured blood parameters in C. furcatus were found to be affected by glyphosate formulation exposure during the study periods. The fish exposed to sublethal concentrations of glyphosate formulation had lower erythrocyte sedimentation rate, red blood cells, hematocrit, and haemoglobin $(\mathrm{Hb} \%)$ content compared with the control. Similar findings were reported when freshwater fish C. gariepinus and $O$. niloticus were exposed to endosulfan [51]. Reduction of TEC and $\mathrm{Hb} \%$ may be suggestive of an appreciable decline in the hematopoiesis leading to various types of anemia [52]. Diseases and other environmental stressors can inhibit or elicit total leucocyte counts (TLC) and the degree of elevation often indicates the severity of the stress. Increase in the TLC in fish treated with glyphosate formulations might be due to the presence of toxic substances or may be associated with the pollutant induced tissue damage as was also stated in
[53]. Generally, the haemathological indices obtained in fish treated with the mixture of glyphosate formulation and $G$. kola seeds extract (group C-D) were within the normal ranges for fish [54]. However, the G. kola seed extract treatment is dose dependent with group D (G. kola seed extract treated with $250 \mathrm{mg} / \mathrm{L}$ extract) being promising.

\subsection{Metabolites}

4.3.1. Carbohydrates. Changes in carbohydrates metabolism have been suggested as useful general indicator of stress in teleost [55]. Reference [56] also reported that blood glucose appeared to be a sensitive indicator of environmental stress and high levels of blood glucose are caused by disorders in carbohydrate metabolism appearing in the condition of physical and chemical stresses [57]. The significant $(P<0.05)$ elevation of carbohydrates metabolism in $C$. furcatus exposed to glyphosate formulation alone may be due to mobilization of muscle and hepatic glycogen [58]. Stress elicits rapid secretion of glucocorticoids and catecholamines from adrenal tissue of the fish. These hormones suppress insulin secretion from the pancreas, promote gluconeogenesis in the liver, and inhibit glucose uptake in peripheral tissues [59]. Therefore, hyperglycemia condition registered in the present study may be ascribed to glyphosate induced hypersecretion of this hormone which causes glycolysis in the liver and muscle of fish. Reference [60] reported that tilapia showed marked hyperglycemic response to stressed environmental conditions as a result of incomplete metabolism of the blood sugar due to impaired osmoregulation. Carbohydrates metabolism in fish treated with the mixture of glyphosate formulation and $G$. kola seed extract (C-D) is dose dependent with group D (glyphosate formulation treated with $250 \mathrm{mg} / \mathrm{L} \mathrm{G}$. kola 
seed extract) normalising the glucose levels after 28 days, an indication of antihyperglycemic property of the plant extract. Corroborating the therapeutic nature of herb in regulating carbohydrates metabolism is the observation reported when ethanolic extracts (50\%) of Caesalpinia bonducella seeds normalized the blood sugar in streptozotocin (STZ) diabetic rats [61]. In the same way administration of aqueous extract of Aegle marmelos leaves improves digestion and reduces blood sugar, urea, and serum cholesterol in alloxanized rats as compared to control. Along with exhibiting hypoglycemic activity, this extract also prevented peak rise in blood sugar at 1 hour in oral glucose tolerance test [62].

When the extract was increased to $350 \mathrm{mg} / \mathrm{L}$, there was inhibition of glucose secretion, an indication that overdose could be detrimental to fish. Similar to this finding is the work of [63] that reported hypoglycemic activity of aqueous extract of Mangifera indica in either normoglycemic or streptozotocin induced diabetic rats. In the same way, ethanolic extracts of $M$. charantia $(200 \mathrm{mg} / \mathrm{kg})$ showed an antihyperglycemic and also hypoglycemic effects in normal and STZ diabetic rats [64].

4.3.2. Protein. It is obvious that exposure of fish for a long time to most toxicants including pesticides interferes with protein metabolism. Increases, protein level reported in glyphosate treated fish may be attributed to stress mediated immobilization of these compounds leading to an increase in energy demands by the fish to cope with environmental condition caused by the toxicant [65]. Also, proteins are functional molecules; it is possible that any complications related to alteration of glucose level are related to defective synthesis of certain proteins since the amount of mitochondrial protein present is closely related to the rate of ATP [65]. The recovery mechanism to Garcinia kola is spontaneous. The result indicated that protein metabolism in the treated fish is dose dependent. Likewise [66] revealed how dried extracts of Coccinia indica (500 mg/kg body weight) regulate the protein and glucose metabolism in human. The extracts restored the activities of enzyme lipoprotein lipase (LPL) that was reduced and glucose-6-phosphatase and lactate dehydrogenase, which were raised in untreated diabetics. Also, oral administration of $500 \mathrm{mg} / \mathrm{kg}$ of $C$. indica leaves showed significant hypoglycemia in alloxanized diabetic dogs and increased glucose tolerance in normal and diabetic dogs [66].

4.3.3. Hydrocortisone. The high secretion of the steroid hormone in glyphosate formulation treated fish may be due to its response to stress caused by the herbicides. Stress heightens hydrocortisone secretion thereby enhancing the breakdown of proteins to provide the fuel to maintain body function and physiological antagonist to insulin by promoting breakdown of carbohydrates and lipids thereby mobilizing energy reserves [67]. The hormone also acts as an anti-inflammatory agent by depressing immune reactions and increases the vasoconstriction caused by epinephrine, a pivotal role in helping the hypothalamus-pituitary-adrenal axis to adjust to stress [68]. It is important to note that increase in hydrocortisone secretion in fish treated with glyphosate formulation can lead to a decrease in insulin sensitivity, increase in insulin resistance, reduced kidney function, hypertension, suppressed immune function, reduced growth hormone levels, and reduced connective tissue strength. This is detrimental to fish, and animals in general including human. This may affect the weight and size of the fish thereby reducing their market values. The hydrocortisone secretion was normalized in G. kola extract treatments and was dose dependent with the treatments $\mathrm{D}$ and $\mathrm{E}$ being most encouraging. Similar results were observed by the authors of [69] when they administered Lycopodium spores to rat. The rats first received carcinogens known to elevate cortisol and reduce testosterone. Subsequent administration of Lycopodium spores decreased cortisol and increased testosterone secretion.

\section{Conclusion}

Glyphosate formulation is a toxic chemical and its sublethal concentrations can alter fish blood chemistry. However, Garcinia kola, a medicinal plant, has provided raw material for innovative, useful, and promising antidote to environmental glyphosate and other xenobiotics contaminations. Therefore, the area that is prone to pollution especially aquatic environment should be treated with right quantity of Garcinia kola seed extract to neutralize the contaminants effects. A further study is therefore required on how the extract of Garcinia kola seeds could be formulated into a tablet and capsules to ensure dosage precision that would increase its acceptability.

\section{Conflict of Interests}

The authors declare that there is no conflict of interests regarding the publication of this paper.

\section{References}

[1] J. K. Grover, S. Yadav, and V. Vats, "Medicinal plants of India with anti-diabetic potential," Journal of Ethnopharmacology, vol. 81, no. 1, pp. 81-100, 2002.

[2] R. Weber, L. Christen, M. Loy et al., "Randomized, placebocontrolled trial of Chinese herb therapy for HIV-1- infected individuals," Journal of Acquired Immune Deficiency Syndromes and Human Retrovirology, vol. 22, no. 1, pp. 56-64, 1999.

[3] K. S. Dhaliwal, "Inventor. Method and composition for treatment of diabetes," US Patent. 5886029. 1999, 1999.

[4] S. S. Gupta, S. C. Verma, V. P. Garg, and M. Rai, "Antidiabetic effects of Tinospora cardifolia. I. Effect on fasting blood sugar level, glucose tolerance and adrenaline induced hyperglycaemia," The Indian Journal of Medical Research, vol. 55, no. 7, pp. 733-745, 1967.

[5] P. Ravikumar and C. V. Anuradha, "Effect of fenugreek seeds on blood lipid peroxidation and antioxidants in diabetic rats," Phytotherapy Research, vol. 13, pp. 197-201, 1999.

[6] P. Khosla, D. D. Gupta, and R. K. Nagpal, "Effect of Trigonella foenum graecum (Fenugreek) on blood glucose in normal and diabetic rats," Indian Journal of Physiology and Pharmacology, vol. 39, no. 2, pp. 173-174, 1995. 
[7] K. Regi Raphael, M. C. Sabu, and R. Kuttan, "Hypoglycemic effect of methanol extract of Phyllanthus amarus Schum \& Thonn on alloxan induced diabetes mellitus in rats and its relation with antioxidant potential," Indian Journal of Experimental Biology, vol. 40, no. 8, pp. 905-909, 2002.

[8] U. J. Okoli, An Investigation into the Hypoglycemic Activity of GB1 Biflavonoids of Garcinia Kola, B. Pharma Project, University of Nigeria, Nsukka, Nigeria, 1991.

[9] O. O. Ebong and T. Korubo-Owiye, "Comparison of the effect of the seeds Garcinia kola on the gastric acid secretion in rats," West African Journal of Pharmacology and Drug Research, vol. 12, pp. 51-54, 1996.

[10] G. C. Onunkwo, H. C. Egeonu, M. U. Adikwu, J. E. Ojile, and A. K. Olowosulu, "Some physical properties of tabletted seed of Garcinia kola (Heckel)," Chemical and Pharmaceutical Bulletin, vol. 52, no. 6, pp. 649-653, 2004.

[11] K. A. Oluyemi, I. O. Omotuyi, O. R. Jimoh, O. A. Adesanya, C. L. Saalu, and S. J. Josiah, "Erythropoietic and anti-obesity effects of Garcinia cambogia (bitter kola) in Wistar rats," Biotechnology and Applied Biochemistry, vol. 46, no. 1, pp. 69-72, 2007.

[12] M. M. Mackeen, A. M. Ali, N. H. Lajis, K. Kawazu, H. Kikuzaki, and N. Nakatani, "Antifungal garcinia acid esters from the fruits of Garcinia atroviridis," Zeitschrift fur Naturforschung C, vol. 57, no. 3-4, pp. 291-295, 2002.

[13] M. M. Iwu, O. A. Igboko, O. K. Elekwa, and M. S. Tempesta, "Prevention of thioacetamide-induced hepatotoxicity by biflavanones of Garcinia kola," Phytotherapy Research, vol. 4, no. 4, pp. 157-159, 1990.

[14] S. B. Olaleye and E. O. Farombi, "Analgesic and Ati inflammatory effects of Kolaviron," African Journal of Biomedical Research, vol. 3, pp. 171-174, 2000.

[15] V. B. Braide, C. A. Agube, G. E. Essien, and F. V. Udoh, "Effect of Garcinia kola seed alkaloid extract on levels of gonadal hormones and pituitary gonadotrophins in rat serum," Nigerian Journal of Physiological Sciences, vol. 18, pp. 59-64, 2003.

[16] A. O. Akpantah, A. A. Oremosu, C. C. Moronhna, J. B. Ekanem, and A. O. Okanlawon, "Effect of Garcinia kola seed extracts on ovulation, oestrous cycle, and foetal Development in Cyclic Sprague Dawley Rats," Nigerian Journal of Physiological Sciences, vol. 20, no. 1-2, pp. 58-562, 2005.

[17] N. Gunsel and J. F. Kanig, "Tablets," in Theory and of Industrial Pharmacy, L. Lachman, H. A. Liberman, J. L. Kanig et al., Eds., Lea and Febiger, Philadelphia, Pa, USA, 2nd edition, 1976.

[18] L. Graves, "Roundup: Birth Defects Caused by World's TopSelling weedkiller," 2011.

[19] R. A. Relyea, "The impact of insecticides and herbicides on the biodiversity and productivity of aquatic communities," Ecological Applications, vol. 15, no. 2, pp. 618-627, 2005.

[20] J. A. Springett and R. A. J. Gray, "Effect of repeated low doses of biocides on the earthworm Aporrectodea caliginosa in laboratory culture," Soil Biology and Biochemistry, vol. 24, no. 12, pp. 1739-1744, 1992.

[21] S. A. Hassan, F. Bigler, H. Bogenschütz et al., "Results of the fifth joint pesticide testing programme carried out by the IOBC/WPRS-Working Group 'Pesticides and beneficial organisms,' Entomophaga, vol. 36, no. 1, pp. 55-67, 1991.

[22] A. Paganelli, V. Gnazzo, H. Acosta, S. L. López, and A. E. Carrasco, "Glyphosate-based herbicides produce teratogenic effects on vertebrates by impairing retinoic acid signaling," Chemical Research in Toxicology, vol. 23, no. 10, pp. 1586-1595, 2010.
[23] J. Doublet, L. Mamy, and E. Barriuso, "Delayed degradation in soil of foliar herbicides glyphosate and sulcotrione previously absorbed by plants: consequences on herbicide fate and risk assessment," Chemosphere, vol. 77, no. 4, pp. 582-589, 2009.

[24] E. Chivian and A. Bernstein, in Threatened Groups of Organisms Valuable to MedicineSustaining Life: How Human Health Depends on Biodiversity, E. Chivian, Ed., p. 209, Oxford University Press, New York, NY, USA, 2008.

[25] J. P. Giesy, S. Dobson, and K. R. Solomon, "Ecotoxicological risk assessment for Roundup herbicide," Reviews of Environmental Contamination and Toxicology, vol. 167, pp. 35-120, 2000.

[26] J. Salbego, A. Pretto, C. R. Gioda et al., "Herbicide formulation with glyphosate affects growth, acetylcholinesterase activity, and metabolic and hematological parameters in Piava (leporinus obtusidens)," Archives of Environmental Contamination and Toxicology, vol. 58, no. 3, pp. 740-745, 2010.

[27] O. A. Oyelese and E. O. Faturoti, "Growth and mortality estimates in Clarias gariepinus fed graded levels of processed cassava peels," Journal of Tropical Forest Resources, vol. 11, pp. 71-81, 1995.

[28] OECD (Organization for Economic Cooperation and Development), Guideline for the Testing of Chemicals, Fish, acute toxicity test, No. 203, 1992.

[29] APHA, AWWA, WEF, Standard Methods for the Examination of Water and Waste Water, American Public Health Association, Washington, DC, USA, 20th edition, 1998.

[30] D. L. Reish and O. S. Oshida, "Manual of methods in aquatic environment research. Part 10. Short- term static Bioassays," FAO Fisheries Technical Paper 247, Rome, Italy, 1987.

[31] D. J. Finney, Probit Analysis, Cambridge University Press, Cambridge, UK, 1971.

[32] OECD, "OECD Guideline for the Testing of Chemicals 407, "Reapeted Dose 28-day Oral Toxicity Study in Rodent," adopted on July 1995, 1997.

[33] C. E. Boyd and C. S. Tucker, Water Quality and Pond Soil Analysis for Aquaculture, vol. 1014, Alabama Agricultural Experiment Station, Auburn University, Auburn, Ala, USA, 1992.

[34] J. L. Congleton and W. J. LaVoie, "Comparison of blood chemistry values for samples collected from juvenile Chinook salmon by three methods," Journal of Aquatic Animal Health, vol. 13, pp. 168-172, 2001.

[35] V. Rusia and S. K. Sood, "Routine haematological test," in Medical Laboratory Technology, K. L. Mukerjee, Ed., pp. 252258, Tata McGraw Hill Publishing, 1992.

[36] H. Bomski, Postawowe Laboratoryjne Badania Hematologiczne. (Basic Laboratory Techniques in Haematology), PZWL, Warsaw, Poland, 1995 (polish).

[37] D. L. Drabkin, "Spectrophotometric studies, XIV, The crystallographic and optimal properties of the haemoglobin of man in comparison with those of other species," Journal of Biological Chemistry, vol. 164, pp. 703-723, 1946.

[38] P. B. Goldenfarb, F. P. Bowyer, E. Hall, and E. Brosious, "Reproducibility in the hematology laboratory: the microhematocrit determination," American Journal of Clinical Pathology, vol. 56, no. 1, pp. 35-39, 1971.

[39] L. R. Murrell and P. F. Nace, "Determination of glucose in fish blood; a modification of the Folin-Malmros microprocedure," Canadian Journal of Biochemistry and Physiology, vol. 36, no. 11, pp. 1121-1124, 1958.

[40] P. Trinder, "Determination of blood glucose using an oxidaseperoxidase system with a non-carcinogenic chromogen," Journal of Clinical Pathology, vol. 22, no. 2, pp. 158-161, 1969. 
[41] O. H. Lowry, N. J. Rosebrough, A. L. Farr, and R. J. Randall, "Protein measurement with the Folin phenol reagent," The Journal of Biological Chemistry, vol. 193, no. 1, pp. 265-275, 1951.

[42] G. Barseghian, R. Levine, and P. Epps, "Direct effect of cortisol and cortisone on insulin and glucagon secretion," Endocrinology, vol. 111, no. 5, pp. 1648-1651, 1982.

[43] S. K. Chiu, C. P. Collier, A. F. Clark, and K. E. Wynn-Edwards, "Salivary cortisol on ROCHE Elecsys immunoassay system: pilot biological variation studies," Clinical Biochemistry, vol. 36, no. 3, pp. 211-214, 2003.

[44] A. Petrie and P. Watson, Statistics for Veterinary and Animal Science, vol. 1, Blackwell Science, Oxford, UK, 1st edition, 1999.

[45] R. A. Fisher, Statistical Methods for Research Workers, Oliver and Boyd, London, UK, 11th edition, 1950.

[46] A. K. Sinha, V. P. Singh, and K. Srivastava, "Physico-chemical studies on river Ganga and its tributaries in Uttar Pradesh-the present status," in Pollution and Biomonitoring of Indian Rivers, R. K. Trevedi, Ed., ABD publishers, Jaipur, India, 2000.

[47] A. M. Kalwale and A. Padmakar, "Determination of physicochemical parameters of Deoli Bhorus dam water," Advances in Applied Science Res, vol. 3, pp. 273-279, 2012.

[48] M. A. Haniffa and S. M. Vijayarani, "Hematological effects of textile mill effluent on freshwater fish Oreochromis mossambicus (Trewaves)," Indian Journal of Experimental Biology, vol. 27, no. 5, pp. 476-478, 1989.

[49] M. Z. Vosyliene and N. Kazlauskiene, "Evaluation of the Svede pond water effect on fish (after accidental discharge of the Kairiai dump filtrate into the environment) and management of water bodies," in Proceedings of the International Scientific Conference, pp. 219-223, Kaunas, 2004.

[50] T. O. Ikpesu, Responses of Clarias gariepinus and Oreochromis niloticus to endosulfan [Ph.D. thesis], Department the Department of Animal and Environmental Biology, University of Benin Nigeria, 2010.

[51] N. Seth and K. K. Saxena, "Hematological responses in a freshwater fish Channa punctatus due to fenvalerate," Bulletin of Environmental Contamination and Toxicology, vol. 71, no. 6, pp. 1192-1199, 2003.

[52] "Fresh water," in Handbook of Ecotoxicology, P. Calins, Ed., vol. 68 of Osneymeed OX 20EL, p. 73, Black Well Science, 1995.

[53] Z. Svobodova, D. Ravds, and J. Palackova, Unified Methods of Haematological Examination of Fish, Research Institute of Fish Culture and Hydrobiology, Vodňany, Czech Republic, 1991.

[54] V. Lusková, M. Svoboda, and J. Kolářová, "The effect of diazinon on blood plasma biochemistry in carp (Cyprinus carpio L.)," Acta Veterinaria Brno, vol. 71, no. 1, pp. 117-123, 2002.

[55] J. Nemcsok and L. Boross, "Comparative studies on the sensitivity of different fish species to metal pollution," Acta Biologica Academiae Scientiarum Hungaricae, vol. 33, no. 1, pp. 23-27, 1982.

[56] G. Wedemeyer, D. J. Mcleay, and C. P. Good year, "Assessing the tolerance of fish and fish population to environmental stress. The problems and methods of monitoring," in Contaminant Effects on Fisheries, W. V. Cairns, P. V. Hodson, and J. O. Nriagu, Eds., pp. 164-195, John Wiley and Son, New York, NY, USA, 1981.

[57] N. N. Sing and A. K. Srivastava, "Effects of endosulfan on fish carbohydrate metabolism," Ecotoxicology and Environmental Safety, vol. 5, pp. 412-417, 1981.

[58] R. C. Andrews and B. R. Walker, "Glucocorticoids and insulin resistance: old hormones, new targets," Clinical Science, vol. 96, no. 5, pp. 513-523, 1999.
[59] E. Omoregie, E. B. C. Ofodike, and R. I. Keke, “Tissue chemistry of Oreochromis niloticus exposed to sublethal concentration of gammalin-20 and acetellic -25EC," Journal of Aquatic Science, vol. 5, pp. 33-36, 1990.

[60] S. R. Sharma, S. K. Dwivedi, and D. Swarup, "Hypoglycaemic, antihyperglycaemic and hypolipidemic activities of Caesalpinia bonducella seeds in rats," Journal of Ethnopharmacology, vol. 58, no. 1, pp. 39-44, 1997.

[61] E. H. Karunanayake, J. Welihinda, S. R. Sirimanne, and G. Sinnadorai, "Oral hypoglycaemic activity of some medicinal plants of Sri Lanka," Journal of Ethnopharmacology, vol. 11, no. 2, pp. 223-231, 1984.

[62] A. O. Aderibigbe, T. S. Emudianughe, and B. A. Lawal, "Antihyperglycemic effect of Mangifera indica in rat," Phytotherapy Research, vol. 13, pp. 504-507, 1999.

[63] B. A. Shibib, L. A. Khan, and R. Rahman, "Hypoglycaemic activity of Coccinia indica and Momordica charantia in diabetic rats: depression of the hepatic gluconeogenic enzymes glucose6-phosphatase and fructose-1,6-bisphosphatase and elevation of both liver and red-cell shunt enzyme glucose-6-phosphate dehydrogenase," Biochemical Journal, vol. 292, no. 1, pp. 267270, 1993.

[64] F. Jenkins, J. Smith, B. Rajanna et al., "Effect of sub-lethal concentrations of endosulfan on hematological and serum biochemical parameters in the carp Cyprinus carpio," Bulletin of Environmental Contamination and Toxicology, vol. 70, no. 5, pp. 993-997, 2003.

[65] M. Takahashi and D. A. Hood, "Protein import into subsarcolemmal and intermyofibrillar skeletal muscle mitochondria: differential import regulation in distinct subcellular regions," Journal of Biological Chemistry, vol. 271, no. 44, pp. 2728527291, 1996.

[66] S. M. Kamble, P. L. Kamlakar, S. Vaidya, and V. D. Bambole, "Influence of Coccinia indica on certain enzymes in glycolytic and lipolytic pathway in human diabetes," Indian Journal of Medical Sciences, vol. 52, no. 4, pp. 143-146, 1998.

[67] J. Du, Y. Wang, R. Hunter et al., "Dynamic regulation of mitochondrial function by glucocorticoids," Proceedings of the National Academy of Sciences of the United States of America, vol. 106, no. 9, pp. 3543-3548, 2009.

[68] R. Lösel and M. Wehling, "Nongenomic actions of steroid hormones," Nature Reviews Molecular Cell Biology, vol. 4, no. 1, pp. 46-56, 2003.

[69] S. Pathak, A. Banerjee, S. Paul, and A. R. Khuda-Bukhsh, "Protective potentials of a plant extract (Lycopodium clavatum) on mice chronically fed hepato-carcinogens," Indian Journal of Experimental Biology, vol. 47, no. 7, pp. 602-607, 2009. 

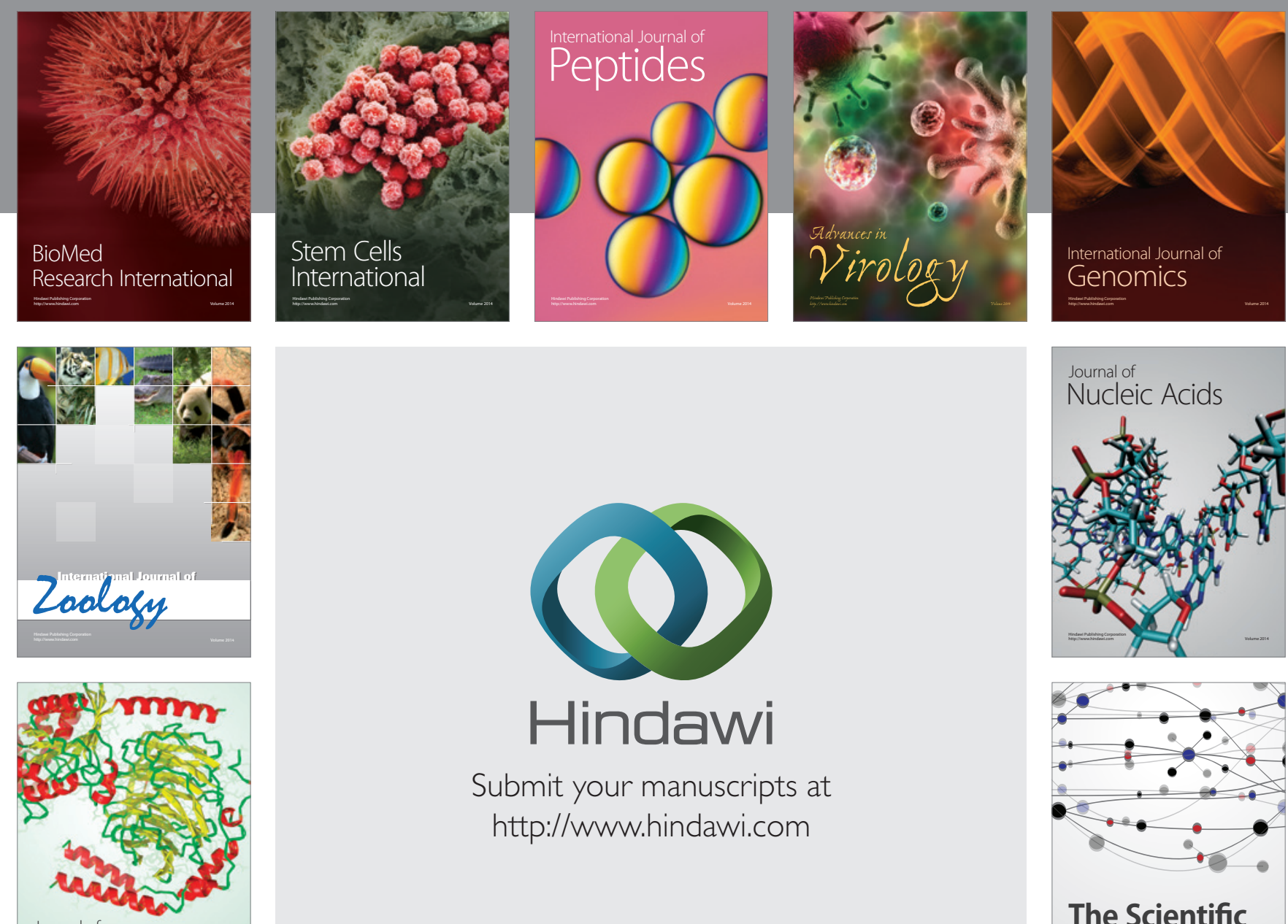

Submit your manuscripts at

http://www.hindawi.com

Journal of
Signal Transduction
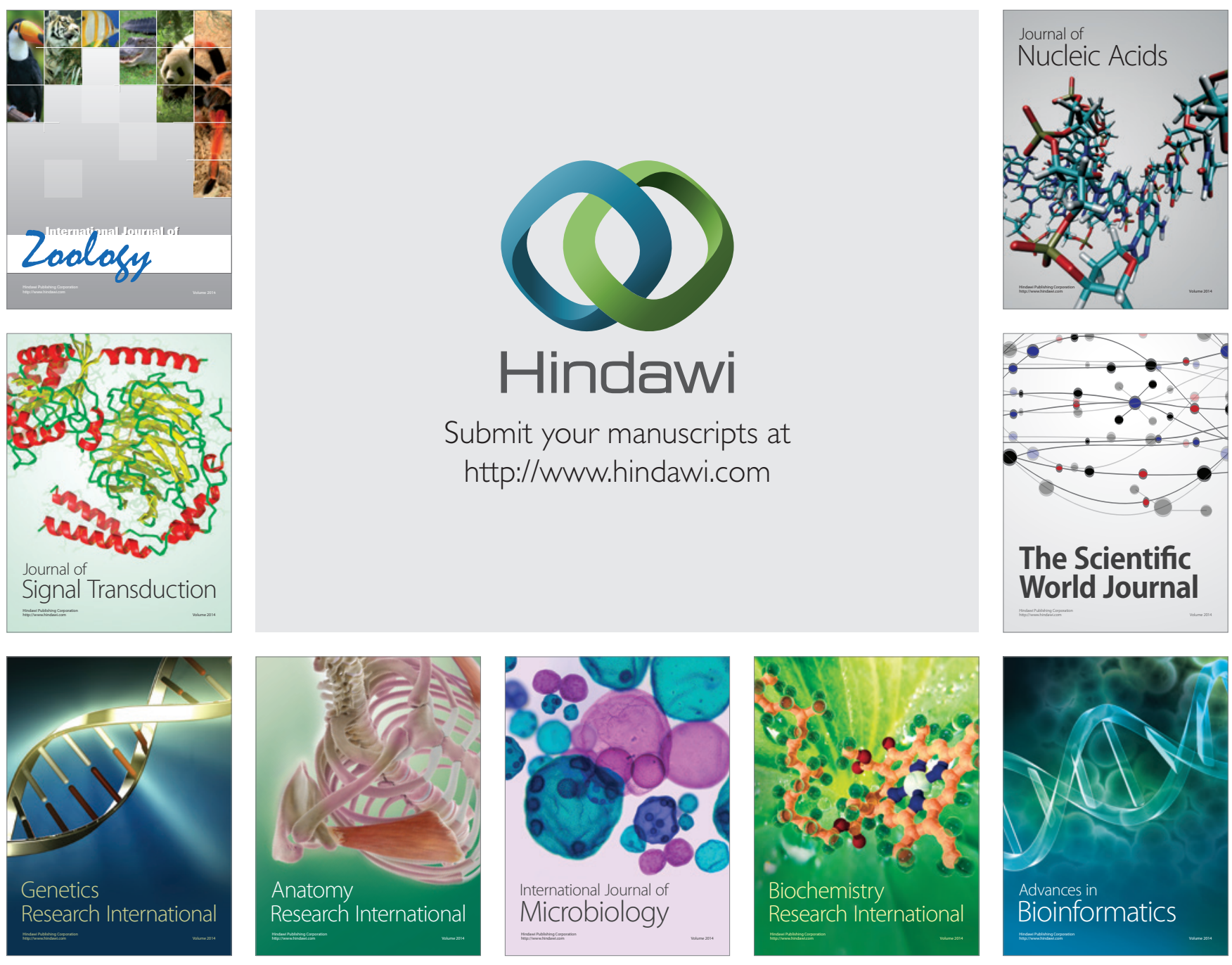

The Scientific World Journal
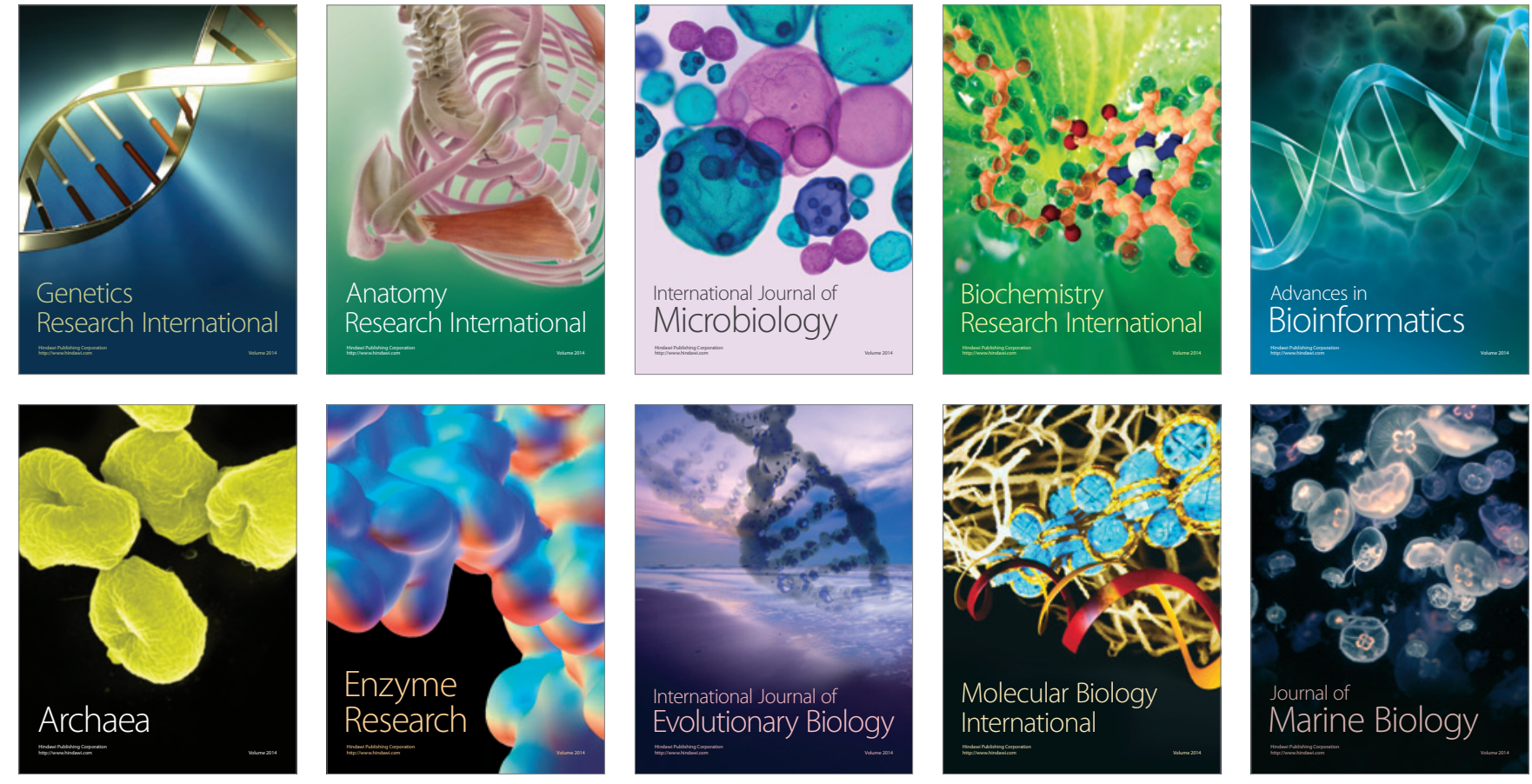